\title{
Modulation of Insulin Receptor, Insulin Receptor Substrate-1, and Phosphatidylinositol 3-Kinase in Liver and Muscle of Dexamethasone-treated Rats
}

\author{
Mario J. A. Saad, Franco Folli, Jeffrey A. Kahn, and C. Ronald Kahn \\ Research Division, Joslin Diabetes Center, Department of Medicine, Brigham and Women's Hospital, \\ and Harvard Medical School, Boston, Massachusetts 02215
}

\begin{abstract}
Insulin rapidly stimulates tyrosine kinase activity of its receptor resulting in phosphorylation of its cytosolic substrate, insulin receptor substrate-1 (IRS-1), which in turn associates with phosphatidylinositol 3-kinase (PI 3-kinase), thus activating the enzyme. Glucocorticoid treatment is known to produce insulin resistance, but the exact molecular mechanism is unknown. In the present study we have examined the levels and phosphorylation state of the insulin receptor and IRS-1, as well as the association/activation between IRS-1 and PI 3-kinase in the liver and muscle of rats treated with dexamethasone.

After dexamethasone treatment ( $1 \mathrm{mg} / \mathrm{kg}$ per $\mathrm{d}$ for $5 \mathrm{~d}$ ), there was no change in insulin receptor concentration in liver of rats as determined by immunoblotting with antibody to the COOH-terminus of the receptor. However, insulin stimulation of receptor autophosphorylation determined by immunoblotting with antiphosphotyrosine antibody was reduced by 46.7 $\pm 9.1 \%$. IRS-1 and PI 3-kinase protein levels increased in liver of dexamethasone-treated animals by 73 and $25 \%$, respectively $(P<0.05)$. By contrast, IRS-1 phosphorylation was decreased by $31.3 \pm 10.9 \%(P<0.05)$, and insulin stimulated $P I$ 3-kinase activity in anti-IRS-1 immunoprecipitates was decreased by $79.5 \pm 11.2 \%(P<0.02)$.

In muscle, the changes were less dramatic, and often in opposite direction of those observed in liver. Thus, there was no significant change in insulin receptor level or phosphorylation after dexamethasone treatment. IRS-1 and PI 3-kinase levels were decreased to 38.6 and $65.6 \%$, respectively $(P<0.01$ and $P$ $<0.05)$. IRS-1 phosphorylation showed no significant change in muscle, but insulin-stimulated IRS-1 associated PI 3-kinase was decreased by $41 \%$. Thus, dexamethasone has differential effects on the proteins involved in the early steps in insulin action in liver and muscle. In both tissues, dexamethasone treatment results in a reduction in insulin-stimulated IRS-1-associated PI 3-kinase, which may play a role in the pathogenesis of insulin resistance at the cellular level in these animals. $(J$.
\end{abstract}

Address correspondence to C. Ronald Kahn, M.D., Joslin Diabetes Center, One Joslin Place, Boston, MA 02215.

Received for publication 31 March 1993 and in revised form 25 June 1993.

J. Clin. Invest.

(c) The American Society for Clinical Investigation, Inc.

0021-9738/93/10/2065/08 $\$ 2.00$

Volume 92, October 1993, 2065-2072
Clin. Invest. 1993.92:2065-2072.) Key words: insulin resistance $\bullet$ animal models $\bullet$ tyrosine kinase $\bullet$ insulin receptor substrate $\bullet$ phosphatidylinositol 3-kinase

\section{Introduction}

Insulin initiates its metabolic and growth-promoting effects by binding to the $\alpha$ subunit of its tetrameric receptor, thereby activating the tyrosine kinase in the $\beta$ subunit $(1,2)$. This catalyzes the intramolecular autophosphorylation of specific tyrosine residues of the $\beta$ subunit further enhancing the tyrosine kinase of the receptor toward other protein substrates (3). In most cells, this primary event leads to the subsequent tyrosyl phosphorylation of a cytoplasmic protein with an apparent molecular mass between 160 and $185 \mathrm{kD}$ called insulin receptor substrate 1 (IRS-1 $)^{1}$ (3-5). Considerable evidence demonstrates that insulin receptor tyrosine kinase activity and associated IRS-1 phosphorylation are essential for many, if not all, of the biological effects of insulin $(1,6,7)$. In cells in culture and in vitro, phosphorylated IRS-1 associates with the lipid metabolizing enzyme phosphatidylinositol 3-kinase (PI 3-kinase) resulting in activation of the enzyme (8). Recently, our laboratory has demonstrated that insulin is capable of stimulating PI 3-kinase activity in liver and muscle of the intact animal under physiological conditions and that IRS-1 phosphorylation may play a significant role in the association/activation with PI-3-kinase in vivo (9). Thus, the insulin receptor, IRS-1 and PI-3-kinase represent three of the earliest steps in insulin action, and each of these can be demonstrated in two of the main target tissues for the metabolic actions of insulin in vivo, liver and muscle.

It has long been known that glucocorticoid excess causes insulin resistance (10-15). Hypercortisolemia is associated with increased glucose production by the liver (10), decreased peripheral glucose transport and utilization $(11,13)$, decreased protein synthesis, and increased protein degradation in muscle (16). The mechanisms by which glucocorticoids exert these effects are unknown. Changes in binding of insulin to its receptor after glucocorticoid treatment have been observed, but do not appear to account for the insulin resistance (12). Using purified receptors and artificial substrates in vitro, decreased insulin receptor phosphorylation and kinase activity have been reported to occur in the liver but not in the muscle of dexameth-

1. Abbreviations used in this paper: IRS-1, insulin receptor substrate-1; PI 3-kinase, phosphatidylinositol 3-kinase; PI 3-P, PI 3-phosphate. 
asone-treated animals $(17,18)$. Using anti-IRS-1 and antiphosphotyrosine antibodies, we recently showed that reduced IRS-1 phosphorylation may have an important role in another state of insulin resistance, the ob/ob mouse model of type II diabetes mellitus (19). The role of the expression or phosphorylation of the endogenous substrate for the insulin receptor, IRS-1, and its association/activation with PI 3-kinase in vivo have not been examined in insulin resistance induced by glucocorticoids. In the present study, we have examined the phosphorylation state of the insulin receptor and IRS-1 and the activation of PI 3-kinase after insulin stimulation in vivo, as well as the levels of these three proteins in liver and muscle of dexamethasone-treated rats.

\section{Methods}

\section{Materials}

Reagents for SDS-PAGE and immunoblotting were from Bio-Rad Laboratories (Richmond, CA ). Hepes, antipain, aprotinin, leupeptin, pepstatin, benzamidine hydrochloride, DTT, ATP, phosphatidylinositol4-monophosphate, Triton X-100, Tween 20, glycerol, and bovine serum albumin (fraction V) were from Sigma Chemical Co. (St. Louis, MO). Nonidet NP-40 was from Calbiochem (La Jolla, CA), phosphatidylinositol from Avanti (Alabaster, AL), silica gel thin-layer chromatography plates from Merck (Gibbstown, $\mathrm{NJ}$ ), protein A-sepharose $6 \mathrm{MB}$ from Pharmacia (Uppsala, Sweden), ${ }^{125}$ I-protein A from ICN Biomedicals (Costa Mesa, CA), $\gamma\left[{ }^{32}\right.$ P $]$ ATP from NEN-Dupont (Wilmington, DE) and nitrocellullose paper (BA85, $0.2 \mu \mathrm{m}$ ) was from Schleicher \& Schuell (Keene, NH). Sodium amobarbital (Amytal) and human recombinant insulin (Humulin R) were from Eli Lilly (Indianapolis, IN). Polyclonal antiphosphotyrosine $(\alpha \mathrm{pY})$ antibodies were raised in rabbits and affinity purified on phosphotyramine columns (20). Anti-IRS-1 antibodies were raised in rabbits using a synthetic peptide (Pep 80) derived from the amino acid sequence (YIPGATMGTSPALTGDEAA) corresponding to residues 489-507 of the rat protein and affinity purified on a column prepared by coupling the synthetic peptide to Affi-Gel 10 (Bio-Rad Laboratories) as previously described (4). Anti-rat-PI 3-kinase antiserum was from UBI (Lake Placid, NY). Antiinsulin receptor antibody was raised in rabbits using a synthetic peptide derived from the amino acid sequence (KKNGRILTLPRSNPS) corresponding to the $C$ terminus of the rat protein.

\section{Methods}

Animals and tissue extracts. Male rats $(130-180 \mathrm{~g})$ were allowed access to standard rodent chow and water ad libitum. Rats were injected daily at $\sim 10: 00$ a.m. with $1 \mathrm{mg} / \mathrm{kg}$ dexamethasone or an equal volume of saline (control group) for $5 \mathrm{~d}$. Food was withdrawn 12-14 h before experiments, and studies were performed in parallel for the control and treated rats in each pair.

Rats were anesthetized with sodium amobarbital $(15 \mathrm{mg} / \mathrm{kg}$ body $w t$ intraperitoneally) and used in experiments 10-15 min later, as soon as anesthesia was assured by loss of pedal and corneal reflexes. The abdominal cavity was opened, the portal vein exposed, and $1 \mathrm{ml}$ of normal saline $(0.9 \% \mathrm{NaCl})$ with or without $10^{-5} \mathrm{M}$ insulin was injected. This is equivalent to injection of $60 \mu \mathrm{g}$ of insulin or $\sim 1.5 \mathrm{U}$ per animal. At $30 \mathrm{~s}$, the livers were removed, minced coarsely, and homogenized immediately in $\sim 10 \times$ vol of solubilization buffer $\mathrm{A}$ in a water bath maintained at $100^{\circ} \mathrm{C}$ with a Polytron PTA 20S generator (model PT 10/35; Brinkmann Instruments, Westbury, NY) operated at maximum speed for $30 \mathrm{~s}$. The solubilization buffer A was composed of $1 \%$ SDS, $50 \mathrm{mM}$ Hepes ( $\mathrm{pH} \mathrm{7.4),} 100 \mathrm{mM}$ sodium pyrophosphate, 100 $\mathrm{mM}$ sodium fluoride, $10 \mathrm{mM}$ EDTA, and $10 \mathrm{mM}$ sodium vanadate. The homogenate was heated further to boiling for $10 \mathrm{~min}$ and then cooled in an ice bath for $40 \mathrm{~min}$.
Approximately $90 \mathrm{~s}$ after injection, hindlimb muscles were excised and frozen in liquid nitrogen. The frozen muscles were ground into a fine powder and homogenized by a Polytron PTA 205 generator in $6 \times$ vol of homogenization buffer B (same as buffer A, except that $1 \%$ Triton-X 100 replaced $1 \%$ SDS, and $2 \mathrm{mM}$ PMSF and $0.1 \mathrm{mg} / \mathrm{ml}$ aprotinin were added) at $4^{\circ} \mathrm{C}$. Both extracts were centrifuged at 55,000 rpm at $4^{\circ} \mathrm{C}$ in a rotor (model $70.1 \mathrm{Ti}$; Beckman Instruments, Inc, Fullerton, CA ) for 60 min to remove insoluble material, and the supernatant was used as a sample.

In preliminary experiments, we showed that the maximal phosphorylation of IRS- 1 occurs between 30 and $60 \mathrm{~s}$ in liver and between 1 and $4 \mathrm{~min}$ in muscle after intraportal insulin infusion. Using a 1-ml vol, the concentrations of insulin that give maximal stimulation were $10^{-6}$ and $10^{-5} \mathrm{M}$ insulin for liver and muscle, respectively. For these experiments, we infused $10^{-5} \mathrm{M}$ insulin and extracted liver at $30 \mathrm{~s}$ and muscle at $1.5 \mathrm{~min}$, thus sampling at the peak of phosphorylation events. Dose-response studies of insulin receptor phosphorylation, IRS-1 phosphorylation, and IRS-1-associated PI 3-kinase activity after intraportal infusion in the intact rat show that half-maximal stimulation occurs at physiological postprandial concentration (9). In some experiments, the livers were extracted in a identical way as muscle, and the supernatant solutions of the muscle and livers were used for immunoprecipitation with anti-IRS-1 antibody.

Protein analysis by immunoblotting. The samples were treated with Laemmli sample buffer (21) with $100 \mathrm{mM}$ DTT and heated in a boiling water bath for $4 \mathrm{~min}$. For total extracts, similar size aliquots of sample ( $150 \mu \mathrm{g}$ of protein ) were subjected to SDS-PAGE (6\% tris acrylamide) in a miniature slab gel apparatus (Bio-Rad Laboratories). Electrotransfer of proteins from the gel to nitrocellulose was performed for $1 \mathrm{~h}$ at $90 \mathrm{~V}$ (constant) in the miniature transfer apparatus (Mini-Protean; Bio-Rad Laboratories) as described by Towbin et al. (22) but with $0.02 \%$ SDS added to the transfer buffer to enhance elution of high molecular mass proteins. Nonspecific protein binding to the nitrocellulose was reduced by preincubating the filter overnight at $4^{\circ} \mathrm{C}$ in blocking buffer (3\% BSA, $10 \mathrm{mM}$ Tris ( $\mathrm{pH} 7.5$ ), $150 \mathrm{mM} \mathrm{NaCl}$, and $0.02 \%$ Tween 20). Prestained molecular weight standards were myosin (205 $\mathrm{kD}), \beta$-galactosidase ( $116 \mathrm{kD})$, bovine serum albumin $(80 \mathrm{kD})$, and ovalbumin $(49.5 \mathrm{kD})$.

The nitrocellulose blot was incubated with antiphosphotyrosine antibodies $(\alpha \mathrm{pY}, 0.3 \mu \mathrm{g} / \mathrm{ml})$ or with anti-IRS-1 antibodies $(0.3 \mu \mathrm{g} / \mathrm{ml}$ $\alpha \mathrm{p} 80$ ) diluted in blocking buffer for $4 \mathrm{~h}$ at $22^{\circ} \mathrm{C}$ and washed for $60 \mathrm{~min}$ with the blocking buffer without BSA. The blots were then incubated with $2 \mu \mathrm{Ci}$ of ${ }^{125} \mathrm{I}$-protein $\mathrm{A}(30 \mu \mathrm{Ci} / \mu \mathrm{g})$ in $10 \mathrm{ml}$ of blocking buffer for $1 \mathrm{~h}$ at $22^{\circ} \mathrm{C}$ and washed again as described above for $2 \mathrm{~h} .{ }^{125} \mathrm{I}$-protein $\mathrm{A}$ bound to the antiphosphotyrosine and anti-IRS-1 antibodies was detected by autoradiography using preflashed Kodak XAR film with Cronex Lightning Plus intensifying screens at $-70^{\circ} \mathrm{C}$ for $12-48 \mathrm{~h}$. Band intensities were quantitated by optical densitometry (Molecular Dynamics, Sunnyvale, CA) of the developed autoradiogram.

Phosphatidylinositol 3-kinase activity. PI 3-kinase activity was measured by in vitro phosphorylation of phosphatidylinositol as previously described $(9,23)$. After insulin injection into the portal vein, a portion of the left lobe of liver and the hindlimb skeletal muscle were removed and homogenized immediately in $(1 / 10 \mathrm{wt} / \mathrm{vol})$ ice-cold solubilization buffer (buffer C) with a Polytron PTA 20S generator (model PT 10/35; Brinkmann Instruments) operated at maximum speed for $30 \mathrm{~s}$ and left to sit on ice for $30 \mathrm{~min}$. The solubilization buffer $C$ was composed of $50 \mathrm{mM}$ Hepes ( $\mathrm{pH} 7.5$ ), $137 \mathrm{mM} \mathrm{NaCl}, 1 \mathrm{mM}$ $\mathrm{MgCl}_{2}, 1 \mathrm{mM} \mathrm{CaCl}_{2}, 2 \mathrm{mM} \mathrm{Na}_{3} \mathrm{VO}_{4}, 10 \mathrm{mM}$ sodium pyrophosphate, $10 \mathrm{mM}$ sodium fluoride, $2 \mathrm{mM}$ EDTA, $1 \%$ NP-40, $10 \%$ glycerol, 2 $\mu \mathrm{g} / \mathrm{ml}$ aprotinin, $10 \mu \mathrm{g} / \mathrm{ml}$ antipain, $5 \mu \mathrm{g} / \mathrm{ml}$ leupeptin, $0.5 \mu \mathrm{g} / \mathrm{ml}$ pepstatin, $1.5 \mathrm{mg} / \mathrm{ml}$ benzamidine, and $34 \mu \mathrm{g} / \mathrm{ml} \mathrm{PMSF}$. Insoluble material was removed by centrifugation at $15,000 \mathrm{rpm}$ in a rotor (model 70Ti; Beckman Instruments, Inc.) for 50 min. IRS-1 was immunoprecipitated from aliquots of the supernatant containing $12 \mathrm{mg}$ protein with anti-IRS-1 $(0.3 \mu \mathrm{g} / \mathrm{ml} \alpha$ pep80) or preimmune rabbit IgG $(0.3 \mu \mathrm{g} / \mathrm{ml})$ followed by protein A-Sepharose 6MB. The immunoprecipitates were washed successively in PBS containing 1\% NP-40 and 
$100 \mu \mathrm{M} \mathrm{Na}{ }_{3} \mathrm{VO}_{4}$ (three times), $100 \mathrm{mM}$ Tris ( $\mathrm{pH} 7.5$ ) containing 500 $\mathrm{mM} \mathrm{LiCl}_{2}$, and $100 \mu \mathrm{M} \mathrm{Na}_{3} \mathrm{VO}_{4}$ (three times), and $10 \mathrm{mM}$ Tris (pH 7.5) containing $100 \mathrm{mM} \mathrm{NaCl}, 1 \mathrm{mM}$ EDTA, and $100 \mu \mathrm{M} \mathrm{Na} \mathrm{VO}_{4}$ (two times). The pellets were resuspended in $50 \mu \mathrm{l}$ of $10 \mathrm{mM}$ Tris ( $\mathrm{pH}$ $7.5)$ containing $100 \mathrm{mM} \mathrm{NaCl}$ and $1 \mathrm{mM}$ EDTA. $10 \mu 1$ of $100 \mathrm{mM}$ $\mathrm{MgCl}_{2}$ and $10 \mu \mathrm{l}$ of phosphatidylinositol $(2 \mu \mathrm{g} / \mu \mathrm{l})$ sonicated in $10 \mathrm{mM}$ Tris ( $\mathrm{pH} 7.5$ ) with $1 \mathrm{mM}$ EGTA were added to each pellet.

The PI 3-kinase reaction was started by the addition of $10 \mu \mathrm{l}$ of 440 $\mu \mathrm{M}$ ATP containing $30 \mu \mathrm{Ci}\left[{ }^{32} \mathrm{P}\right.$ ] ATP. After $10 \mathrm{~min}$ at room temperature with constant shaking, the reaction was stopped by the addition of $20 \mu 18 \mathrm{~N} \mathrm{HCl}$ and $160 \mu \mathrm{l} \mathrm{CHCl} /$ methanol (1:1). The samples were centrifuged, and the lower organic phase was removed and applied to a silica gel TLC plate (Merck) coated with $1 \%$ potassium oxalate. TLC plates were developed in $\mathrm{CHCl}_{3} / \mathrm{CH}_{3} \mathrm{OH} / \mathrm{H}_{2} \mathrm{O} / \mathrm{NH}_{4} \mathrm{OH}$ (60:47:11.3:2), dried, and visualized by autoradiography. The radioactivity in spots that comigrated with a PI-4 standard was measured by Cerenkov counting.

\section{Other}

Plasma glucose levels were determined with a glucose analyzer (Beckman Instruments) on blood samples from the cava vena obtained when the animals were killed. Insulin was determined by a standard radioimmunoassay. Protein determination was performed by the Bradford dye method (24) using the Bio-Rad reagent and BSA as the standard.

\section{Statistics}

Experiments were always performed studying samples from the dexamethasone-treated animals in parallel with a control group. Comparisons were made using paired and unpaired $t$ tests as appropriate. The level of significance used was $P<0.05$.

\section{Results}

Characteristics of dexamethasone-treated rats. Table I summarizes the body weight, plasma glucose, and serum insulin levels of control and dexamethasone-treated rats. As previously observed, glucocorticoid excess induces a state of insulin resistance characterized by three- to fourfold increase in blood glucose and a sixfold increase in plasma insulin levels. As a result, the rats treated with dexamethasone also either lost or failed to gain weight during the $5 \mathrm{~d}$ of treatment period. Protein content of the liver and muscle in steroid-treated rats were $251 \pm 9$ and $239 \pm 39 \mathrm{mg} / \mathrm{g}$ tissue, respectively, and in controls, they were $276 \pm 17$ and $217 \pm 28 \mathrm{mg} / \mathrm{g}$ tissue, respectively. The concentration of DNA per gram of hindlimb muscle was somewhat higher in dexamethasone-treated rats compared to controls $(0.995 \mathrm{mg} / \mathrm{g}$ tissue vs $0.780 \mathrm{mg} / \mathrm{g}$ tissue, $P<0.05)$. There was no difference in the DNA content of liver between dexamethasone-treated rats and controls ( $2.89 \mathrm{vs} 3.17 \mathrm{mg} / \mathrm{g}$ tissue $)$. All of the quantitative data have been expressed normalized per milligrams of protein, however, in most situations, similar changes were observed if the data were normalized by DNA content.

Table I. Characteristics of Rats Studied

\begin{tabular}{lcccc}
\hline \multicolumn{1}{c}{ Groups } & $n$ & $\begin{array}{c}\text { Body } \\
\text { weight }\end{array}$ & $\begin{array}{c}\text { Plasma } \\
\text { glucose }\end{array}$ & $\begin{array}{c}\text { Serum } \\
\text { insulin }\end{array}$ \\
\hline & & $g$ & $m g / d l$ & $\mu U / m l$ \\
Control & 12 & $174 \pm 3$ & $88 \pm 3(6)$ & $12 \pm 2(6)$ \\
Dexamethasone & 12 & $139 \pm 4$ & $277 \pm 18(6)$ & $78 \pm 15(6)$ \\
\hline
\end{tabular}

The data are represented as the mean \pm SEM.
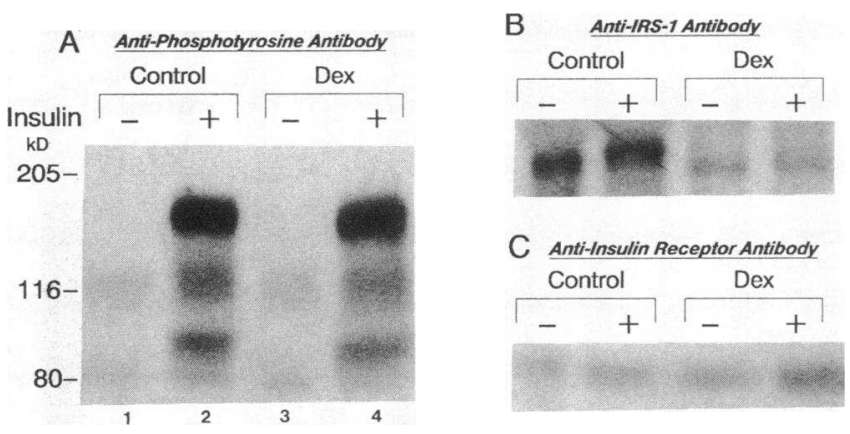

Figure 1. Insulin-stimulated tyrosine phosphorylation in intact muscle from dexamethasone-treated rats. Rats were anesthetized and the abdominal wall was incised to expose the viscera. $1 \mathrm{ml}$ of normal saline (lanes 1 and 3) or $10^{-5} \mathrm{M}$ insulin (lanes 2 and 4) was infused into portal vein as a bolus injection, and $90 \mathrm{~s}$ later, muscles were excised and homogenized in extraction buffer $B$ at $4^{\circ} \mathrm{C}$ as described in Methods. After centrifugation, aliquots with same amount of protein were resolved on $6 \%$ SDS-polyacrylamide gel, transferred to nitrocellulose, and detected with antiphosphotyrosine antibody $(A)$, antiIRS-1 antibody $(B)$, or antiinsulin receptor antibody $(C)$, and ${ }^{125} \mathrm{I}-$ protein $A$, and subjected to autoradiography. Dex, dexamethasone.

Effect of dexamethasone on insulin receptor and IRS-I phosphorylation in muscle of rats. Fig. 1 illustrates the protocol for assessment of insulin receptor signaling in the intact rat. Control and dexamethasone-treated rats were injected with saline or insulin and after 30 and $90 \mathrm{~s}$, the liver and hindlimb skeletal muscle were removed and homogenized as described in Methods, and the extracts subjected to SDS-PAGE under reducing conditions and blotted to nitrocellulose membranes. These blots could then be analyzed using antiinsulin receptor, anti-IRS-1, and antiphosphotyrosine antibodies, while parallel extracts were assayed for PI 3-kinase activity and protein level.

Glucocorticoid-induced insulin resistance was associated with a slight increase in insulin receptor levels in muscle, but dramatically decreased IRS-1 protein levels (Fig. 1). When the results of eight similar experiments were subjected to scanning densitometry, there was a $38.0 \pm 7.1 \%$ increase in insulin receptor levels in muscle of dexamethasone-treated rats in samples normalized per protein as determined by immunoblotting with an antibody to the $\mathrm{COOH}$ terminus of the insulin receptor (Fig. $2 \mathrm{~A}$ ). By contrast, the levels of IRS-1 protein in muscle detected by immunoblotting were decreased by $61.4 \pm 5.0 \%$ in rats treated with dexamethasone for $5 \mathrm{~d}$ (Fig. $2 \mathrm{~A}$ ).

After in vivo insulin stimulation, the extent of insulin receptor autophosphorylation and IRS-1 phosphorylation as determined by immunoblotting with an antiphosphotyrosine antibody were similar in muscle of the dexamethasone-treated and control rats (Figs. $1 A$ and $2 B$ ). However, when the data were corrected for the change in number of insulin receptors and IRS-1 molecules, the results are divergent, with a modest decrease in the apparent stoichiometry of insulin receptor phosphorylation but a more than twofold increase in the stoichiometry of IRS-1 phosphorylation in the dexamethasonetreated rats (Fig. $2 C$ ). Thus, the increase in the phosphorylation of IRS-1 protein as a result of steroid treatment might be of limited biological significance since the number of IRS-1 molecules was dramatically decreased and the overall phosphorylation was slightly reduced when compared to controls (Fig. 1 $A$ ). In some experiments, there was a small difference in electro- 


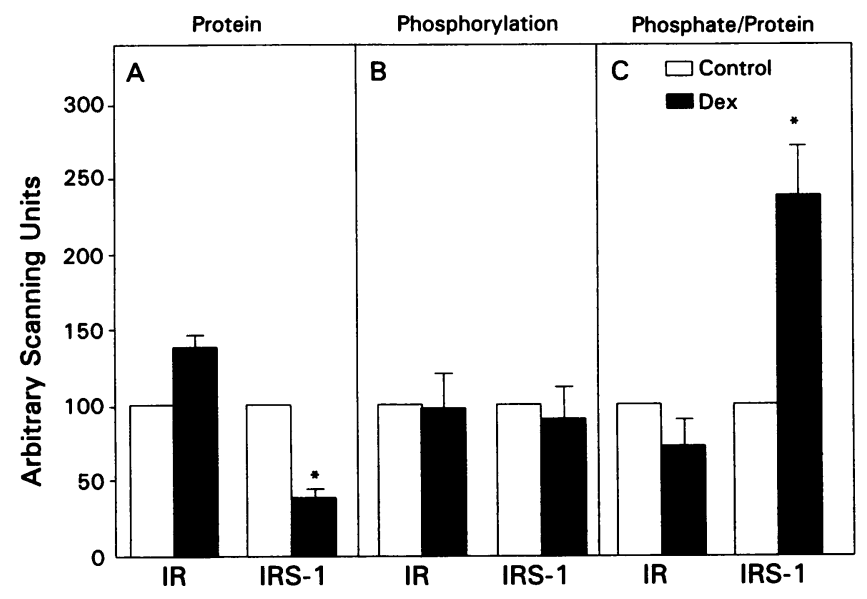

Figure 2. Insulin receptor and IRS-1 protein and tyrosine phosphorylation levels (after in vivo insulin stimulation) in muscle of control and dexamethasone-treated rats. Scanning densitometry of autoradiograms was performed on eight experiments for insulin receptor and IRS-1 concentration and six experiments for tyrosine phosphorylation levels of both. The data are expressed as mean \pm SEM. *Indicates differences statistically significant at least at $P<0.05$.

phoretic mobility in IRS-1 band observed after insulin stimulation because of the change in phosphorylation state, but this was not consistently observed (Fig. $1 B$ ).

Effect of dexamethasone treatment on insulin receptor and IRS-1 phosphorylation in liver in rats. The effect of dexamethasone treatment on insulin receptor and IRS-1 in liver was different from that in muscle. There was no change in insulin receptor level as detected by immunoblotting in liver of animals treated with dexamethasone, whether normalized per protein or DNA (Figs. $3 C$ and $4 A$ ). Furthermore, in contrast to the decrease in IRS- 1 observed in muscle, immunoblotting of liver extracts with antibodies to IRS-1 revealed that the level of IRS-1 was increased by $73.0 \pm 35.3 \%(P<0.05)$ in dexamethasone-treated rats as compared to controls (Figs. $3 B$ and $4 A$ ).

After dexamethasone treatment, changes were observed in both basal and stimulated phosphorylation of the insulin receptor and IRS-1 in liver. Before insulin stimulation, basal insulin receptor phosphorylation was $\sim 36 \%$ higher in dexamethasone-treated rats than in controls, whereas after insulin stimulation the extent of phosphorylation of insulin receptor was reduced by $46.7 \pm 9.1 \%(P<0.05)$ in treated rats compared to controls (Figs. $3 A$ and $4 B$ ). Accordingly, the tyrosine phosphorylation of IRS-1 was increased by $84 \pm 10 \%(P<0.05)$ before insulin stimulation in dexamethasone-treated rats while the level of insulin-stimulated phosphorylation of IRS-1 was reduced by $31.3 \pm 10.9 \%(P<0.05)$ in the presence of glucocorticoid excess (Figs. $3 A$ and $4 B$ ). When the data are expressed as a function of the amount of insulin receptor and IRS-1 molecules, there was a $40-50 \%$ in the stoichiometry of insulin receptor and IRS-1 phosphorylation in the liver of the dexamethasone-treated rats (Fig. $4 \mathrm{C}$ ).

Characteristics of insulin-stimulated PI 3-kinase activity of liver and muscle in vivo in control and dexamethasone treated rats. To determine the impact of changes in IRS-1 expression and phosphorylation on a further downstream effect, rats were injected with saline or insulin as described above, extracts of liver and hindlimb muscle were prepared and immunoprecipi- tated with anti-IRS-1 antibodies, and the washed immunoprecipitates were assayed in vitro for PI-3 kinase activity.

A low level of basal PI-3 kinase activity was present in the anti-IRS-1 immunoprecipitates from liver of control rats corresponding to a relative specific activity of $0.47 \pm 0.07 \mathrm{pmol} /$ $\mathrm{mg}$ protein per min. After insulin stimulation there was a rapid and dramatic 25 -fold increase in IRS- 1 associated PI-3 kinase activity (Fig. $5 \mathrm{~A}$ ). This is similar to magnitude to the increase in IRS-1 phosphorylation that occurs after insulin stimulation. In liver of dexamethasone-treated rats, there was a significantly higher basal level of IRS-1-associated PI-3 kinase activity compared to control rats (specific activity $=1.47 \pm 0.15$ vs $0.47 \pm 0.07 \mathrm{pmol} / \mathrm{mg}$ protein per min, $P<0.05$ ) (Fig. 5). However, after insulin stimulation, there was only a 1.7 -fold increase in the PI 3-kinase activity in liver of dexamethasonetreated rats. Thus, when compared with controls, the levels of insulin-stimulated PI-3 kinase activity in anti-IRS-1 immunoprecipitates was reduced by $79.5 \%$ after dexamethasone treatment (Fig. 5).

In muscle, IRS-1-associated PI 3-kinase activity in the basal state was slightly reduced in dexamethasone-treated rats as compared to controls (specific activity $=1.60 \pm 0.37$ vs $2.21 \pm 0.31 \mathrm{pmol} / \mathrm{mg}$ protein per $\mathrm{min}$ ), although this difference was not statistically significant. After insulin stimulation there were a sevenfold stimulation in PI 3-kinase activity in control rats, but only a fivefold stimulation in muscle of dexamethasone-treated rats despite the lower basal level. Thus, when compared with controls, the absolute level of insulin-stimulated PI 3-kinase activity in anti-IRS-1 immunoprecipitates was reduced by $41.2 \%$ in dexamethasone-treated rats (Fig. 5).

To determine if these changes might be caused by differences in the total amount of PI 3-kinase in tissues of dexamethasone-treated animals, we determined the level of total enzyme protein by immunoblotting the tissue extracts with an antibody to the 85-kD subunit of PI 3-kinase. Based on immunoreactivity, the levels of this enzyme showed a tissue-specific regulation similar to that observed with IRS-1. PI 3-kinase protein levels decreased to $65.5 \pm 14 \%$ of control values in muscle of dexamethasone-treated rats, but increased to $125.0 \pm 9.3 \%$ of control in liver (Fig. 6). These changes paralleled the changes that

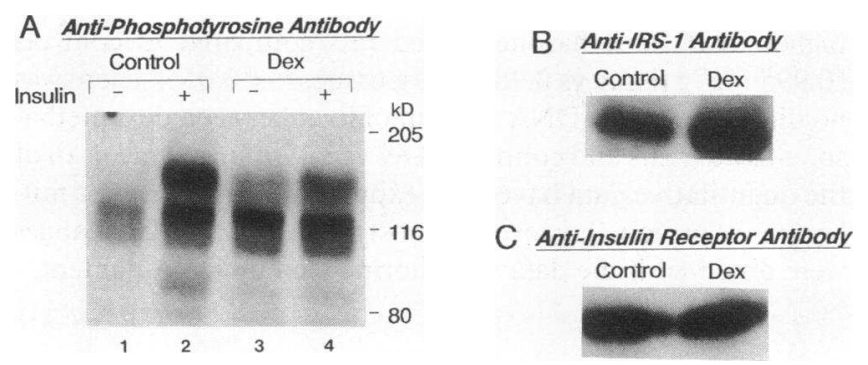

Figure 3. Insulin-stimulated tyrosine phosphorylation in intact liver from rats treated with dexamethasone. Rats were anesthetized and the abdominal wall was incised to expose viscera. $1 \mathrm{ml}$ of normal saline (lanes 1 and 3 ) or $10^{5} \mathrm{M}$ insulin (lanes 2 and 4 ) was injected into portal vein as a bolus, and $30 \mathrm{~s}$ later, the liver was excised and homogenized in extraction buffer $\mathrm{A}$ at $100^{\circ} \mathrm{C}$ for $5 \mathrm{~min}$ as described in Methods. After centrifugation, aliquots with same amount of protein were resolved on $6 \%$ SDS-polyacrylamide gel, transferred to nitrocellulose, and detected with antiphosphotyrosine antibody $(A)$, anti-IRS-1 antibody $(B)$, or antiinsulin receptor antibody $(C)$, and ${ }^{125} \mathrm{I}$-protein $A$, and subjected to autoradiography. 


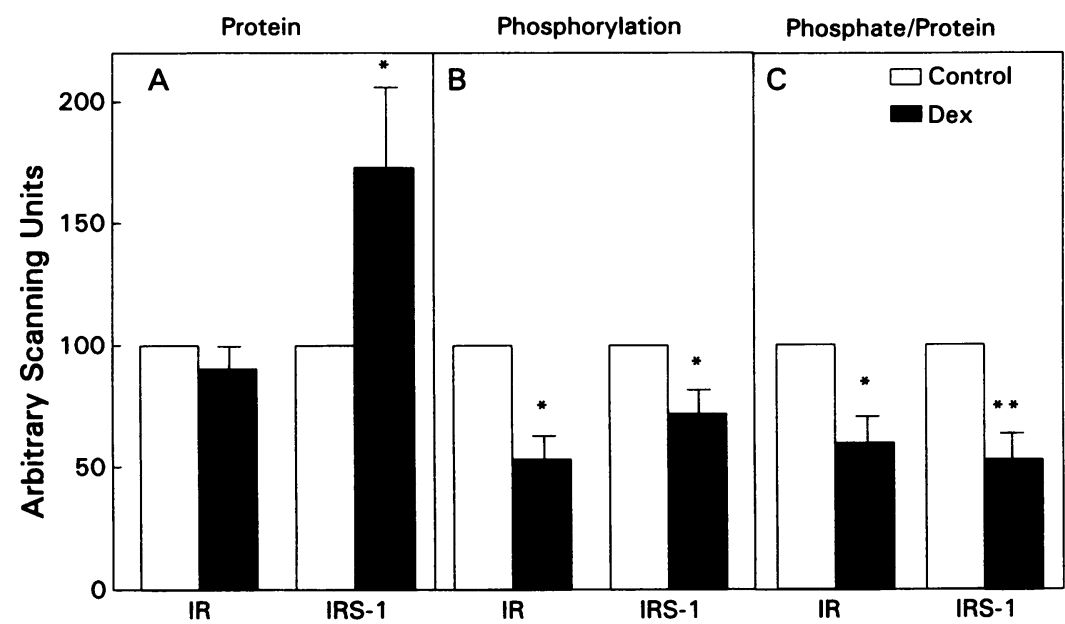

Figure 4. Insulin receptor and IRS-1 protein and tyrosine phosphorylation levels (after in vivo insulin stimulation) in liver of dexamethasone-treated rats. Scanning densitometry was performed on autoradiograms from 8 experiments for insulin receptor concentration, 12 experiments for IRS- 1 concentration, and 12 experiments for tyrosine phosphorylation of both proteins. The data are expressed as mean \pm SEM. ${ }^{*}$ Indicates differences statistically significant at $P$ $<0.05$. occurred in IRS-1 associated PI 3-kinase activity in the basal state and suggest that the levels of IRS-1 and PI 3-kinase might have an important role in the basal association/activation between IRS-1 / PI 3-kinase.

Previous studies by our group $(8,9)$ have suggested that there is a relatively stable high affinity interaction between IRS1 and the $85-\mathrm{kD}$ subunit of the PI 3-kinase, such that both proteins are coprecipitated by antibodies to either protein. In samples from liver previously immunoprecipitated with antiIRS- 1 antibody and immunoblotted with antiphosphotyrosine

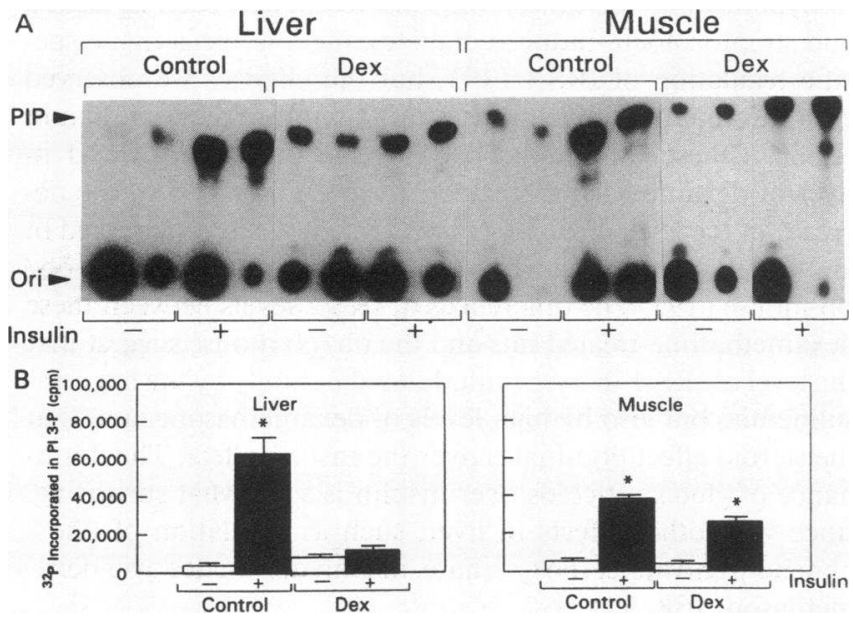

Figure 5. Insulin stimulation of IRS-1 associated PI 3-kinase in liver and muscle of control and dexamethasone-treated rats. The proteins from liver and muscle were extracted and processed as described in Methods, and incubated at $4^{\circ} \mathrm{C}$ with anti-IRS-1 antibodies and protein A-Sepharose. PI 3-kinase in the washed immunoprecipitates was assayed as described in Methods. The resulting labeled lipids were extracted, separated by TLC, and visualized by autoradiography. [ $\left.{ }^{32} \mathrm{P}\right]-$ phosphate incorporated into PI-3P was quantitated by Cerenkov counting. $(A)$ PI 3-kinase activity in anti-IRS-1 immunoprecipitates from liver and muscle after insulin stimulation. Ori indicates the origin; PIP, indicates the position of migration of PI(4)P standard. (B) Quantitation by Cerenkov counting of the $\left[{ }^{32} \mathrm{P}\right]$ phosphate incorporated into PI 3-P in immunoprecipitates from liver and muscle of control and dexamethasone-treated rats. The results are expressed as mean \pm SEM. The differences are statistically significant when control and dexamethasone-treated rats before insulin stimulation in liver and after insulin stimulation in liver and muscle are compared. antibody, there was a $>50 \%$ decrease in insulin stimulated IRS1 phosphorylation in dexamethasone-treated rats, confirming the finding with whole tissue extracts (compare Figs. $3 \mathrm{~A}$ and 7 $A)$. When the same blot was subsequently incubated with antibodies directed against the $85-\mathrm{kD}$ subunit of PI 3-kinase, there was little detectable immunoreactivity in the basal state in normal animals, however this was increased in steroid-treated animals (Fig. $7 \mathrm{~B}$ ), possibly because of the higher basal insulin levels. After insulin stimulation, a band with the expected molecular weight of regulatory subunit of PI 3-kinase ( $85 \mathrm{kD}$ ) was present in anti-IRS-1 immunoprecipitates from liver of both groups of rats consistent with a stable association of IRS- 1 and PI 3-kinase. However, the amount of PI 3-kinase associated with IRS- 1 was reduced $\sim 35 \%$ in dexamethasone-treated rats, suggesting less association between IRS-1/PI 3-kinase. These data are in accordance with the reduction in PI 3-kinase activity in immunoprecipitates of anti-IRS- 1 antibodies in liver of these rats. The same experiment was also done for muscle, and the results showed that after insulin stimulation the amount of immunoreactive PI 3-kinase in immunoprecipitates of antiIRS-1 antibodies was very similar in controls and in dexamethasone-treated rats (data not shown).

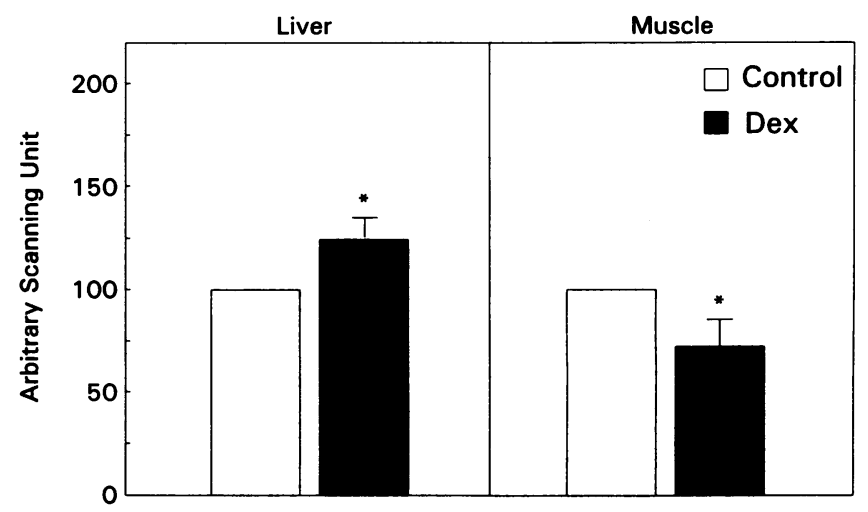

Figure 6. PI 3-kinase levels in liver and muscle of control and dexamethasone-treated rats. The proteins from muscle and liver were extracted and processed as described in legends to Figs. 1 and 3, and detected with anti-PI 3-kinase antibody (p85) and ${ }^{125}$ I-protein A and subjected to autoradiography. The bars represent mean \pm SEM of five experiments for muscle and eight for liver. *Indicates differences from control at $P<0.05$. 

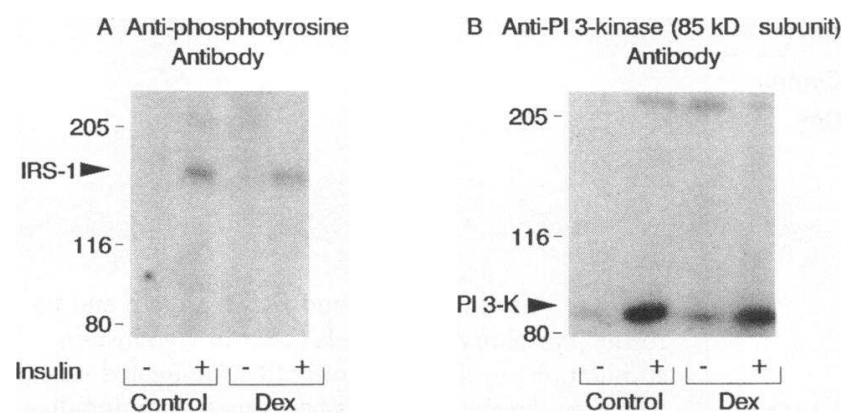

Figure 7. Immunoblotting of tyrosyl phosphorylated proteins and PI 3-kinase in anti-IRS-1 immunoprecipitates from liver of control and dexamethasone-treated rats. The protein from liver were extracted and processed as described in legend of Fig. 3, solubilized and incubated at $4^{\circ} \mathrm{C}$ with anti-IRS antibody and Pansorbin. Immunoprecipitated proteins were analyzed by immunoblotting with antiphosphotyrosine and anti-PI 3-kinase ( $85 \mathrm{kD}$ subunit) antibodies and ${ }^{125} \mathrm{I}$ protein A and subjected to autoradiography.

\section{Discussion}

The exact molecular events linking the insulin receptor tyrosine kinase to its final cellular actions remain poorly understood. Over the past $2 \mathrm{yr}$, however, two newly recognized early steps in the insulin action cascade have been defined at a molecular level. First, insulin stimulates tyrosine phosphorylation of a cytoplasmic protein of relative molecular mass between 165 and $185 \mathrm{kD}$, termed pp185 or IRS-1 (3-5). IRS-1 has been shown to be a direct substrate of the insulin receptor both in vivo and in vitro $(25,26)$. Furthermore, IRS-1 phosphorylation is decreased in intact cells expressing mutant insulin receptors in direct proportion to the decrease in insulin receptor kinase activity (27), and phosphorylation of IRS-1 by the activated insulin receptor can be demonstrated by incubation of baculovirus-produced IRS-1 with purified insulin receptor (25). IRS-1 has multiple potential serine, threonine, and tyrosine phosphorylation sites. Nine of the tyrosine phosphorylation sites have the repetitive sequence motif Tyr-Met-Xxx-Met (YMXM) or Tyr-Xxx-Xxx-Met (YXXM). When phosphorylated these sites, as well as others, appear to be involved in noncovalent interactions of IRS-1 with other signaling molecules, particularly proteins containing $\operatorname{SH} 2$ domains $(5,8,9,28)$.

Thus, tyrosine phosphorylation of IRS- 1 leads to a second early intracellular step in insulin action, an association of IRS1 with the enzyme PI 3-kinase $(8,9)$. The association probably occurs through phosphorylated YMXM motifs on IRS-1 and the $\mathrm{SH} 2$ domain on the $85-\mathrm{kD}$ subunit of the PI 3-kinase $(8,9)$. Insulin also increases the cellular concentration of phosphatidylinositol 3-phosphate (PI 3-P), PI(3, 4)P2, and PI(3, 4, 5)P3, indicating that the PI 3-kinase is activated during insulin stimulation (29-31). The phosphorylation of IRS-1 and the activation of PI 3-kinase is decreased in cells expressing mutant insulin receptors, and the decrease correlates with defective insulin signaling, suggesting that these steps have an important role in insulin action $(23,32)$. Recently, we demonstrated that in a mouse model of insulin resistance and non-insulin-dependent diabetes mellitus (the ob/ob mouse), insulin receptor, IRS-1 phosphorylation, and PI 3-kinase activity are reduced in liver and muscle after insulin stimulation in vivo, pointing to a postbinding defect in insulin action in these animals $(19,33)$. The role of possible alterations in PI 3-kinase in insulin resis- tant states has not yet been studied. In the present study, we have evaluated the role of insulin receptor and IRS-1 phosphorylation and also the association/activation of PI 3-kinase with IRS-1 in liver and muscle of rats treated with dexamethasone.

Dexamethasone treatment of rats induces marked insulin resistance as evidenced by altered glucose metabolism in both peripheral tissues and liver, as well as decreased insulin-stimulated amino acid uptake in muscle, and decreased lipogenesis in adipocytes $(10,11,15,33 \mathrm{a})$. This occurs with no significant change in insulin receptor levels in liver and a small increase in muscle. Dexamethasone has been shown to stimulate the synthesis of insulin receptors in IM-9 lymphocytes (34) and in cultured rat hepatocytes ( 35 ), and to decrease receptor degradation in 3T3 mouse fibroblasts (36). Thus, any downregulation caused by increased circulating insulin levels in the dexamethasone-treated rats is probably offset by effects of glucocorticoids on receptor synthesis and/or degradation.

Despite the normal number of receptors in liver and the slight increase in receptors in muscle, we found $\sim 40-50 \%$ reduction in insulin receptor autophosphorylation after insulin stimulation in vivo in both tissues. In muscle this may or may not be of biological significance, since the decrease in receptor phosphorylation was offset completely by the increase in receptor number. These findings are consistent with previous studies from our laboratory (17) and others $(18,37)$.

The changes in IRS-1 levels in dexamethasone-treated rats show a tissue-specific regulation decreasing by $61 \%$ in muscle and increasing by $73 \%$ in liver. Recently, we demonstrated that in hypoinsulinemic states of insulin resistance, such as fasting and streptozotocin-induced diabetes, there is also a tissue-specific regulation of IRS-1 (19), but the changes we observed after dexamethasone administration are more marked than in either of these conditions. The increase in levels of IRS-1 in liver of dexamethasone-treated rats are in contrast to the decrease in the level of IRS-1 in liver, which we have observed in another hyperinsulinemic model of insulin resistance, the ob/ ob mouse (19). The differences in IRS-1 levels between these dexamethasone-treated rats and the ob/ob mouse suggest that the level of IRS-1 in liver is modulated not only by the hyperinsulinemia, but also by high levels of dexamethasone, and that the steroid effect dominates over the insulin effect. The dominance of glucocorticoids over insulin is somewhat surprising, since with other effects in liver, such as regulation of phosphoenolpyruvate-carboxy kinase, insulin dominates over dexamethasone $(38,39)$.

In addition to the differing effects of glucocorticoids on IRS-1 protein levels in liver and muscle, there is a differential effect on the stoichiometry of phosphorylation of IRS-1, which is reduced by $60 \%$ in liver and increased by $136 \%$ in muscle of dexamethasone-treated rats. The findings in liver are in agreement with the decrease in insulin receptor phosphorylation in kinase activity observed in that tissue, reinforcing our previous observation that IRS-1 phosphorylation may depend more on insulin receptor phosphorylation and kinase activity than IRS1 protein levels (19). The finding in muscle is difficult to explain, but suggests that there can be differential coupling between insulin receptor autophosphorylation and its ability to catalyze IRS-1 phosphorylation. Since the concentration of IRS- 1 in liver and muscle is normally similar to that of the receptor, it is possible that the increase in the ratio of insulin receptor protein to IRS-1 protein in muscle of dexamethasone- 
treated rats increases the efficiency of coupling between the enzyme and its substrate.

Interestingly, PI 3-kinase levels also showed tissue specific regulation in the dexamethasone-treated rats which was similar but less dramatic than the glucocorticoid effect on IRS-1. The increased levels of IRS-1 and PI 3-kinase protein in liver and the decreased levels in muscle in dexamethasone-treated rats correlate with the changes in basal PI 3-kinase activity in antiIRS-1 immunoprecipitates from these tissues and suggest that the levels of these proteins has an important role in the process of association/activation in the basal state. The activation of PI 3-kinase immunoprecipitated with anti-IRS-1 antibody after insulin stimulation was dramatically reduced in both tissues of dexamethasone-treated rats, but especially so in liver. This is in accordance with the decrease in level of phosphorylated IRS-1 in muscle and the reduced stoichiometry of IRS-1 phosphorylation in liver.

The differences in insulin receptor and IRS- 1 phosphorylation and also IRS-1 associated PI 3-kinase activity between liver and muscle in glucocorticoid-treated rats is interesting and may reflect a tissue specific regulation of these three steps in insulin action. Alternatively, this may reflect chronic exposure of these tissues to different levels of insulin, since liver is exposed to higher insulin levels than muscle. The reduction in these initial steps after insulin binding in liver appears to be regulatory, since similar alterations are observed in other animal models of insulin resistance associated with hyperinsulinemia (19) and in cultures of rat hepatoma cells chronically treated with insulin (Saad et al., manuscript in preparation ). It is important to emphasize that in muscle, the major site of glucose disposal (40), the decrease in PI 3-kinase activation in dexamethasone-treated rats was less than that observed in liver, suggesting that the insulin resistance in this tissue might also involve steps distal to IRS-1 phosphorylation and IRS-1-associated PI 3-kinase activity.

In summary, this study shows reduced expression and/or phosphorylation of insulin receptor and IRS-1 may lead to reduced association and activation of PI 3-kinase in vivo in liver and muscle of dexamethasone-treated rats. These data suggest that changes in these early steps in insulin signal transduction may have an important role in the insulin resistance observed in these animals.

\section{Acknowledgments}

The authors wish to thank Drs. Lewis Cantley (Tufts Medical School), as well as Morris F. White and Montserrat Miralpeix (Joslin Diabetes Center) for kindly providing antibodies to PI 3-kinase, anti-IRS-1, and antiphosphotyrosine, Jonathan Backer (Joslin Diabetes Center) for many helpful suggestions, and Ms. Terri-Lyn Bellman for excellent secretarial assistance.

This work was supported in part by National Institutes of Health grants DK-33201 (C. R. Kahn), DK-36836 (Joslin's Diabetes and Endocrinology Research Center grant), and the Marilyn Simpson Family Trust. Dr. Franco Folli is a recipient of Dottorato di Ricerca, University of Milano, School of Medicine, Italy. During this work, Dr. Saad held a fellowship from CNPq, Brazil.

\section{References}

1. Rosen, O. 1987. After insulin binds. Science (Wash. DC). 237:1452-1458.

2. Kasuga, M., F. A. Karisson, and C. R. Kahn. 1982. Insulin stimulates the phosphorylation of the 95,000 dalton subunit of its own receptor. Science (Wash. DC). 215:185-187.
3. White, M. F., R. Maron, and C. R. Kahn. 1985. Insulin rapidly stimulates tyrosine phosphorylation of a $M_{\mathrm{r}} 185,000$ protein in intact cells. Nature (Lond.). 318:183-186.

4. Rothenberg, P. L., W. S. Lane, A. Karasik, J. Backer, M. F. White, and C. R. Kahn. 1991. Purification and partial sequence analysis of pp185, the major cellular substrate of the insulin receptor tyrosine kinase. J. Biol. Chem. 266:8302-8311.

5. Sun X. J., P. L. Rothenberg C. R. Kahn, J. M. Backer, E. Araki, P. Wilden, D. A. Cahill, B. J. Goldstein, and M. F. White. 1991. Structure of the insulin receptor substrate IRS-1 defines a unique signal transduction protein. Nature (Lond.). 352:73-77.

6. Maegawa, H., J. M. Olefsky, S. Thies, D. Boyd, A. Ullrich, and D. A. McClain. 1988. Insulin receptors with defective tyrosine kinase inhibit normal receptor function at the level of substrate phosphorylation. J. Biol. Chem. 263:12629-12637.

7. Ebina, Y., E. Araki, M. Taira, F. Shimada, M. Mori, C. S. Craik, K. Siddle, S. B. Pierce, R. A. Roth, and W. J. Rutter. 1987. Replacement of lysine residue 1030 in the putative ATP-binding region of the insulin receptor abolishes insulinand antibody-stimulated glucose uptake and receptor kinase activity. Proc. Natl. Acad. Sci. USA. 84:704-708.

8. Backer, J. M., M. G. Myers, Jr., S. E. Shoelson, D. J. Chin, X. J. Sun, M. Miralpeix, P. Hu, B. Margolis, E. Y. Skolnik, J. Schlessinger, and M. F. White. 1992. The phosphatidylinositol 3-kinase is activated by association with IRS-1 during insulin stimulation. EMBO (Eur. Mol. Biol. Organ.) J. 11:3469-3479.

9. Folli, F., M. J. A. Saad, J. M. Backer, and C. R. Kahn. 1992. Insulin stimulation of phosphatidylinositol 3-kinase activity and association with IRS-1 in liver and muscle of the intact rat. J. Biol. Chem. 267:22171-22177.

10. Amatruda, J. M., J. N. Livingston, and D. H. Lockwood. 1985. Cellular mechanisms in selected states of insulin resistance: human obesity glucocorticoid excess and chronic renal failure. Diab. Metab. Rev. 3:293-317.

11. DePirro, R., A. Green, Y. Kao, and J. M. Olefsky. 1981. Effects of prednisone and dexamethasone in vivo and in vitro. Studies of insulin binding, deoxyglucose uptake and glucose oxidation in rat adipocytes. Diabetologia. 21:149153.

12. Kahn, C. R., I. D. Goldfine, D. M. Neville, Jr., and P. DeMeyts. 1978. Alterations in insulin binding induced by changes in vivo in the levels of glucocorticoids and growth hormone. Endocrinology. 103:1054-1066.

13. Olefsky, J. M. 1975. Effect of dexamethasone on insulin binding, glucose transport, and glucose oxidation of isolated rat adipocytes. J. Clin. Invest. 56:1499-1508.

14. Olefsky, J. M., J. Johnson, F. Lier, P. Jen, and G. M. Reaven. 1975. The effects of acute and chronic dexamethasone administration on insulin binding to isolated rat hepatocytes and adipocytes. Metabolism. 24:517-527.

15. Caro, J. F., and J. M. Amatruda. 1982. Glucocorticoid-induced insulin resistance. J. Clin. Invest. 69:866-875.

16. Rannels, S. R., and L. S. Jefferson. 1980. Effects of glucocorticoids on muscle protein turnover in perfused rat hemicorpus. Am. J. Physiol. 238:E564E572.

17. Karasik, A., and C. R. Kahn. 1988. Dexamethasone-induced changes in phosphorylation of the insulin and EGF receptors and their substrates in intact rat hepatocytes. Endocrinology. 123:2214-2222.

18. Block, N. E., and M. G. Buse. 1989. Effects of hypercortisolemia and diabetes on skeletal muscle insulin receptor function in vitro and in vivo. $\mathrm{Am}$. J. Physiol. 256:E39-E45.

19. Saad, M. J. A., E. Araki, M. Miralpeix, P. L. Rothenberg, M. F. White, and C. R. Kahn. 1992. Regulation of insulin receptor substrate 1 in liver and muscle of animal models of insulin resistance. J. Clin. Invest. 90:1839-1849.

20. Pang, D. T., B. R. Sharma, and J. A. Shafer. 1985. Purification of the catalytically active phosphorylated form of insulin receptor kinase by affinity chromatography with O-phosphotyrosyl-binding antibodies. Arch. Biochem. Biophys. 242:176-186.

21. Laemmli, U. K. 1970. Cleavage of structural proteins during the assembly of the head of bacteriophage T4. Nature (Lond.). 227:680-685.

22. Towbin, H., J. Staehlin, and J. Gordon. 1979. Electrophoretic transfer of proteins from polyacrylamide gels to nitrocellulose sheets: procedure and some applications. Proc. Natl. Acad. Sci. USA. 76:4350-4354.

23. Backer, J. M., G. G. Schroeder, C. R. Kahn, M. G. Myers, Jr., P. A. Wilden, D. A. Cahill, and M. F. White. 1992. Insulin stimulation of phosphatidylinositol 3-kinase activity maps to insulin receptor regions required for endogenous substrate phosphorylation. J. Biol. Chem. 267:1367-1374.

24. Bradford, M. M. 1976. A rapid and sensitive method for the quantitation of microgram quantities of protein utilizing the principle of protein dye binding. Anal. Biochem. 72:248-254.

25. Sun, X. J., M. Miralpeix, M. G. Myers, Jr, E. M. Glasheen, J. M. Backer, C. R. Kahn, and M. F. White. 1992. Expression and function of IRS-1 in insulin signal transmission. J. Biol. Chem. 267:22662-22672.

26. Tobe, K., O. Koshio, Y. Tashiro-Hashimoto, F. Takaku, Y. Akanuma and $M$. Kasuga. 1990. Immunological detection of phosphotyrosine-containing proteins in rat livers after insulin injection. Diabetes. 39:528-533.

27. Wilden, P. A., J. M. Backer, C. R. Kahn, D. A. Cahill, G. J. Schroeder, and 
M. F. White. 1990. The insulin receptor with phenylalanine replacing tyrosine1146 provides evidence for separate signals regulating cellular growth and metabolism. Proc. Natl. Acad. Sci. USA. 87:3358-3362.

28. Koch, C. A., D. Anderson, M. F. Moran, C. Ellis, and T. Pawson. 1991. SH2 and SH3 domains: elements that control interactions of cytoplasmic signaling proteins. Science (Wash. DC). 252:668-674.

29. Ruderman, N. B., R. Kapeller, M. F. White, and L. C. Cantley. 1990 Activation of phosphatidylinositol 3-kinase by insulin. Proc. Natl. Acad. Sci. USA. 87:1411-1415.

30. Kelly, K. L., N. B. Ruderman, and K. S. Chen. 1991. Phosphatidylinosito 3-kinase in isolated rat adipocytes. Activation by insulin and subcellular distribution. J. Biol. Chem. 267:3423-3428.

31. Endemann, G., K. Yonezawa, and R. A. Roth. 1990. Phosphatidylinosito kinase or an associated protein is a substrate for the insulin receptor tyrosine kinase. J. Biol. Chem. 265:396-400.

32. Kapeller, R., K. S. Chen, M. Yoakim, B. S. Schaf fhausen, J. M. Backer, M. F. White, L. C. Cantley, and N. B. Ruderman. 1991. Mutations in the juxtamembrane region of the insulin receptor impair activation of phosphatidylinositol 3-kinase by insulin. Mol. Endocrinol. 5:769-777.

33. Folli, F., M. J. A. Saad, J. M. Backer, and C. R. Kahn. 1993. Regulation of phosphatidylinositol 3-kinase activity in liver and muscle of animal models of insulin-resistant and muscle-deficient diabetes mellitus. J. Clin. Invest. 92:17871794.

33a. Haber, R. S., and S. P. Weinstein. 1992. Role of glucose transporters in glucocorticoid-induced insulin resistance. GLUT-4 isoform in rat skeletal muscle is not decreased by dexamethasone. Diabetes. 41:728-735.

34. Fantus, G., G. A. Saviolakis, J. A. Hedo, and P. Gorden. 1982. Mechanism of glucocorticoid-induced increase in insulin receptors of cultured human lymphocytes. J. Biol. Chem. 257:8277-8283.

35. Salhanick, A. I., M. N. Knipp, and J. M. Amatruda. 1983. Dexamethasone stimulates insulin receptor synthesis in cultured rat hepatocytes. J. Biol. Chem. 258:14130-14135.

36. Knutson, V. P. 1986. The acute and chronic effects of glucocorticoids on insulin receptor and insulin responsiveness. Transient fluctuations in intracellular receptor level parallel transient fluctuations in responsiveness. J. Biol. Chem. 261:10306-10312.

37. Truglia, J. A., G. R. Hayes, and D. H. Lockwood. 1988. Intact adipocyte insulin-receptor phosphorylation and in vitro tyrosine kinase activity in animal models of insulin resistance. Diabetes. 37:147-153.

38. O'Brien, R. M., and D. K. Granner. 1990. PEPCK gene as model of inhibitory effects of insulin on gene expression. Diabetes Care. 13:327-339.

39. Gunn, J. M., S. M. Tilghman, R. W. Hanson, L. Reshef, and F. J. Ballard. 1975. Effects of cyclic adenosine monophosphate dexamethasone and insulin on phosphoenolpyruvate carboxykinase synthesis in reuber H-35 hepatoma cells. Biochemistry. 14:2350-2357.

40. Ferrannini E., O. Bjorkman, G. A. Reichard, Jr., A. Pilo, M. Olsson, J. Wahren, and R. A. DeFronzo. 1985. The disposal of an oral glucose load in healthy subjects. A quantitative study. Diabetes. 34:580-588. 